\title{
1A1-A4＼cjkstart培養心筋細胞の拍動と電気活動の同時観測
}

\section{Simultaneous recording of electrical activity and contraction from cultured cardiomyocytes}

\section{○尾崎 友彦*，倉島 利明"，高山祐三**，森本晃司 ${ }^{* *}$ ，李鐘国 ${ }^{* * *}$ ，}

児玉逸雄 ${ }^{* *}$ ，小林英津子"，佐久間一郎*，神保泰彦"*

\section{*東京大学大学院新領域創成科学研究科, ${ }^{* *}$ 東京大学大学院工学系研究科, ***名古屋大学環境医学研究所}

Tomohiko OZAKI, Toshiaki KURASHIMA, Yuzo TAKAYAMA, Koji MORIMOTO, LEE Jong-Kuk, Itsuo KODAMA, Etsuko KOBAYASHI, Ichiro SAKUMA, Yasuhiko JIMBO

${ }^{*}$ Graduate School of Frontier Sciences, University of Tokyo

${ }^{*}{ }^{*}$ Graduate School of Engineering, University of Tokyo

** * Research Institute of Environmental Medicine, Nagoya University

\section{1.はじめに}

心臟は，心筇細胞の同期拍動とそのタイミングの微妙な制 御により，ポンプ機能を実現している。この制御機榡の障害 により発生するのが不整脈現象である，現在，細胞レベルて その詳細な発生メカニズムの解明，効果的な治療法の確立に 向けて研究が進められている状況にある. 本研究では，微小 電極アレイ基板上で培養した心筋細胞系を利用したアプロー チを行う。電極アレイ基板はマイクロ電極を多数集樌化した 細胞培養基板であり，非侵㜔的に電気活動計測・多点電気刺 激が可能であることが特徽である. 薬物投与等の手段により この系に不整脈現象を誘導し，これに時空間的に制御した電 気刺激パターンを適用してその伝播を阻止する可能性につい て検討する．今回，その第 1 段階としてラット胎児から採取 した心筋細胞を微小電極アレイ基板上で培養し，その同期拍 動と活動電位発生の同時計測を行ったので，その結果を報告 する.

\section{2. 实殹方法}

微小電極アレイは， $30 \times 30 \mu \mathrm{m}$ の記録電極が 64 個，中心 間隔 $180 \mu \mathrm{m}, 8 \times 8$ のアレイ状に並べられているものを使用 した．今回の実埃では，胎齢 18 日の Wistar Rat より心筋紐

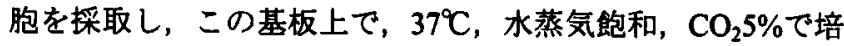
養を行った。培美液には M199 培地に $10 \% \mathrm{FBS}$ を加えたもの を使用し，1 週間に 3 度，全量交換した。

試料は倒立影微鏡ステージ上に設貫し，周囲をアクリル製 の简易インキュベータとして $37^{\circ} \mathrm{C}$, 水蒸気飽和, $\mathrm{CO}_{2} 5 \%$ の 囲気に保持した．基板電極で記録される信号を $12 \mathrm{bit}, 25 \mathrm{kHz}$ でA/D 変換し，LabViewを用いて計測した．また，同期拍動 の測定系には CCD カメラを用いた。

\section{3. 实硂結果}

培養開始 6 DIV (Days in vitro)における微小電極アレイ基板 上の培恙心㬳細胞を Fig.1 に示す．また，同試料の自発的電 気活動を計測した結果を Fig.2に示す。

培美開始後数日以内に細胞の拍動が観測された. Fig.2に示 寸電気信号は，観測された拍動現象に比へてて発生頻度が高い

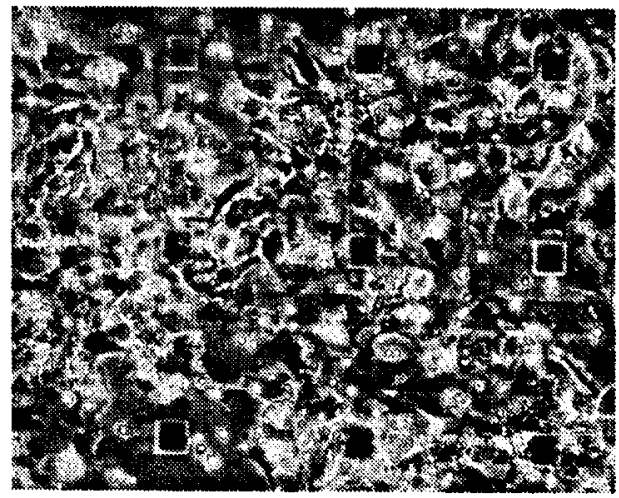

Fig.1 Cultured cardiomyocytes on the microelectrode array

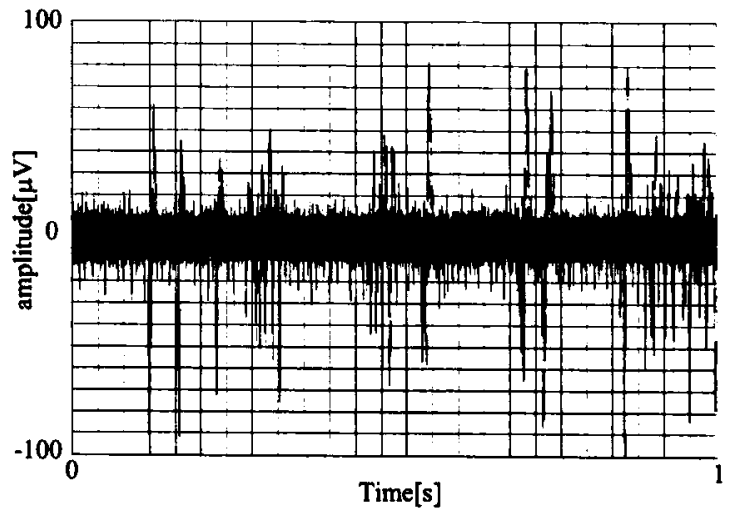

Fig.2 Spontaneous activity of cultured cardiomyocytes と考えられる.この時点では系全体の同期拍動には至ってい なかったなどの状況が考えられるが，今後さらにデータを蕃 程し，検討を進める。

\section{4. 今後の予定}

今回の実験では，培義心筋細胞の同期拍動と活動電位の同 時計測を行ったが，薬品や電気刺激による抗不整脈作用の検 討には至っていない，そこで，今回䅺築した测定系を基に微 小電極アレイの特徵を活かし，非侵熟的多点電気刺激や薬品 投与を組み合わせ，その作用機序を検討していく予定である。

第 3 回生活支嗳工学系学会連合大会（2005 年 12 月、三重） 